\title{
Decision-making efficiency, accountability and democracy in inter-municipal cooper- ation arrangements: The case of Iceland
}

\author{
Grétar Pór Eypórsson, Professor, University of Akureyri
}

\section{Útdráttur}

Samstarf sveitarfélaga á Íslandi á sér margra áratuga sögu. Ekki síst hefur samstarf smærri sveitarfélaga og stærri verið títt og pá einkum með pað að markmiði að bæta og efla pá pjónustu sem veitt er borgurunum. Slíkt hefur reynst hinum smærri sveitarfélögum pung praut vegna smæðar peirra og par með skorts á bolmagni til að veita pjónustu. Í pessari grein er viðfangsefnið að rýna í hinar lýðræðislegu hliðar á samstarfi sveitarfélaga. Rannsóknarspurningarnar snúa að áhrifum slíks samstarfs á lýðræði, pólitíska ábyrgð og skilvirkni í ákvarðanatöku. Evrópskir fræðimenn hafa bent á vandkvæði við pað hvernig samstarf hinna lýðræðislegra kjörnu eininga getur vakið upp spurningar sem tengjast pessum lýðræðislegum páttum. Til að leitast við að svara pessu hvað Ísland varðar er stuðst við gögn úr tveimur könnunum meðal íslenskra sveitarstjórnarmanna par sem peir voru spurðir út í pessi atriði. Meginniðurstaðan er að sveitarstjórnarmenn á Íslandi telja pessi vandkvæði vera til staðar í samstarfsverkefnum sveitarfélaga, einkum pó er varðar óskýra pólitíska ábyrgð og skort á skilvirkni í ákvarðanatöku.

Efnisorð: Samstarfsverkefni sveitarfélaga; pólitísk ábyrgð; lýðræði; skilvirkni.

\begin{abstract}
Inter-municipal cooperation in Iceland has a history of many decades. There has been significant cooperation between smaller and larger municipalities in order to improve the provision of services, which in many cases has been difficult for the small and smallest units - a question of capacity. In this article, the main task is to look at the democratic aspect of inter-municipal cooperation arrangements. The main research questions are on consequences for democracy, democratic
\end{abstract}

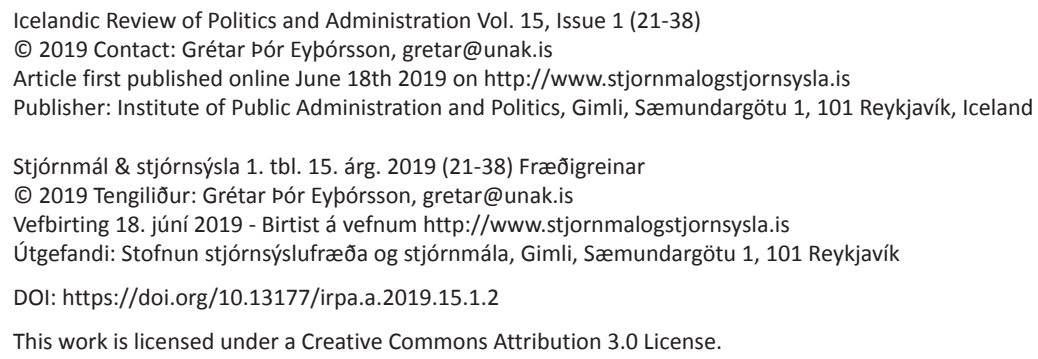


accountability, efficiency and decision-making in this context, which have been pointed out as the main democratic concerns by various European researchers. To answer this for the case of Iceland, responses to questions on the topic from two different surveys among local leaders are analysed. The main conclusion is that the general concerns stated by the above-mentioned researchers also seem to be present in the case of inter-municipal cooperation in Iceland.

Keywords: Inter-municipal cooperation; democratic accountability; democracy; efficiency.

\section{Introduction}

Attempts to reinforce the local government system in Iceland in various ways have been periodically ongoing since World War 2. The main characteristic of the system has been its fragmentation. The proportionally high number of very small municipalities has been a problem through the years, particularly in the context of the expanding welfare state with increasing tasks for the public sphere - not least in welfare services at local level. In Iceland, the main emphasis has been on reform through municipal amalgamations - enlarging the municipalities in order to be able to take over more tasks from the state and better cope with functions for which they are already responsible (Eythórsson 2012). This has been done through two comprehensive local referenda on municipal amalgamations, first in 1993 and then in 2005. Despite the fact that municipal amalgamations are fully voluntary for each municipality through citizen referenda, the number of municipalities has decreased by 63 percent since 1993 - from 196 to 72. Looking further back, to 1973 , the reduction is almost 70 percent - the proportional reduction of municipalities in Europe for the period is only higher in Greece and Belgium (Steiner et al. 2016). The promoters of reforms have, however, repeatedly pointed out that the system needs further refinement, preferably through larger municipal units. In the past 10 years or so, the main emphasis in reinforcing the municipal level has been on establishing inter-municipal cooperation arrangements instead of amalgamating municipalities. Researchers focusing on inter-municipal cooperation have, in many cases, pointed out that cost-efficiency, scale-economy and capacity can be gained or are at least expected to be gained by IMC arrangements and, therefore, among the primary drivers behind municipalities entering cooperation arrangements (Eythórsson 2018; Jacobsen 2014; Swianiewicz 2011; Baldersheim \& Rose 2010; Hulst \& van Montfort 2007; Lundtorp \& Weber 2001). Thus it comes as no surprise that a significant number of municipalities, especially the smaller ones, have preferred this alternative to amalgamations.

One can ask whether the reality is as simple as that. Some researchers have pointed out democratic problems and democratic concerns of various kinds connected with municipalities participating in inter-municipal cooperation arrangements. Lack of efficiency in decision making in these contexts and insufficient transparency in decisionmaking in inter-municipal cooperation arrangements, have been highlighted as the negative sides of the coin (see for example Kjær 2000; Swianiewicz 2011; Denters 2017; Teles \& Swianiewicz 2018). In most cases, this kind of arrangement means that director 
boards or committees for cooperation arrangements are established. They have board members from most or all municipalities involved, as well as a managing director responsible to each board. Therefore, the IMC boards or councils are not directly elected in the respective municipalities.

In this article, I intend to focus on certain democracy problems in inter-municipal cooperation contexts and try to answer the question whether these could also apply to inter-municipal cooperation arrangements in Iceland. This has not been studied earlier for the Icelandic context and would provide additional material for a European comparison.

To answer this I will rely on material from two different surveys where elected local councilors were asked about various aspects relating to inter-municipal cooperation. The main questions concern inter-municipal cooperation arrangements and their consequences for democracy, democratic accountability, efficiency and decision-making in this context, where directly locally elected councils delegate some of their power to arrangements resulting from cooperation with similar local political units.

Section 1, provides a background to the local government system in Iceland, its fragmentation and the functions of the municipalities, as well as to municipal reforms and developments. Section 2, discusses the experience, the academic debate, the motives, and democratic consequences relating to inter-municipal cooperation arrangements. In section 3, the two local leaders' surveys are analysed. The analysis attempts to answer the question as to whether democratic concerns regarding the situation in some European countries also apply in Iceland. Section 4 sums up the results and tries to evaluate whether these democratic concerns about inter-municipal cooperation arrangements deserve special consideration when this softer way of territorial rescaling is chosen instead of the harder option of amalgamating municipalities.

\section{On the municipal level in Iceland}

A main characteristic of the Icelandic local government system is the proportionally great number of sparsely populated municipalities. This is evident in a European comparative perspective (Baldersheim \& Rose 2010, 3; Karlsson \& Jóhannesson 2014, 18). The very smallest municipalities are often agricultural communities even without any villages and a population close to 50 inhabitants. At the same time, the capital of Reykjavík has a population of 126,000 . The small units are proportionally numerous. Even though the mean size is about 4500, the median size is only just below 900 . Due to the fragmentation, one could have guessed that local level expenditures do not involve high figures - the fact is that these are only $30.9 \%$ of total public spending ${ }^{1}$ - which is quite low in comparison with the other Nordic countries where local (and regional) level expenditure is between 60 and 70 percent. Nevertheless, a broad range of services are provided by local governments, either all by themselves or in cooperation with the state. Education (primary schools, kindergartens and music schools) is by far the biggest task of the Icelandic municipalities. Social Services and Youth, Leisure and Sport follow with less than half of the expenditures in comparison. ${ }^{2}$ 


\subsection{Development}

Historically, the number of municipalities in Iceland reached its peak of 229 in 1950. The changes in structure, with a reduction down to 72 today, have primarily taken place after 1990. The following figure illustrates the changes in municipal structure in a historical context. In 2006, municipalities with a population of less than 1000 were almost 70 percent of all municipalities but today this rate is 54 percent.

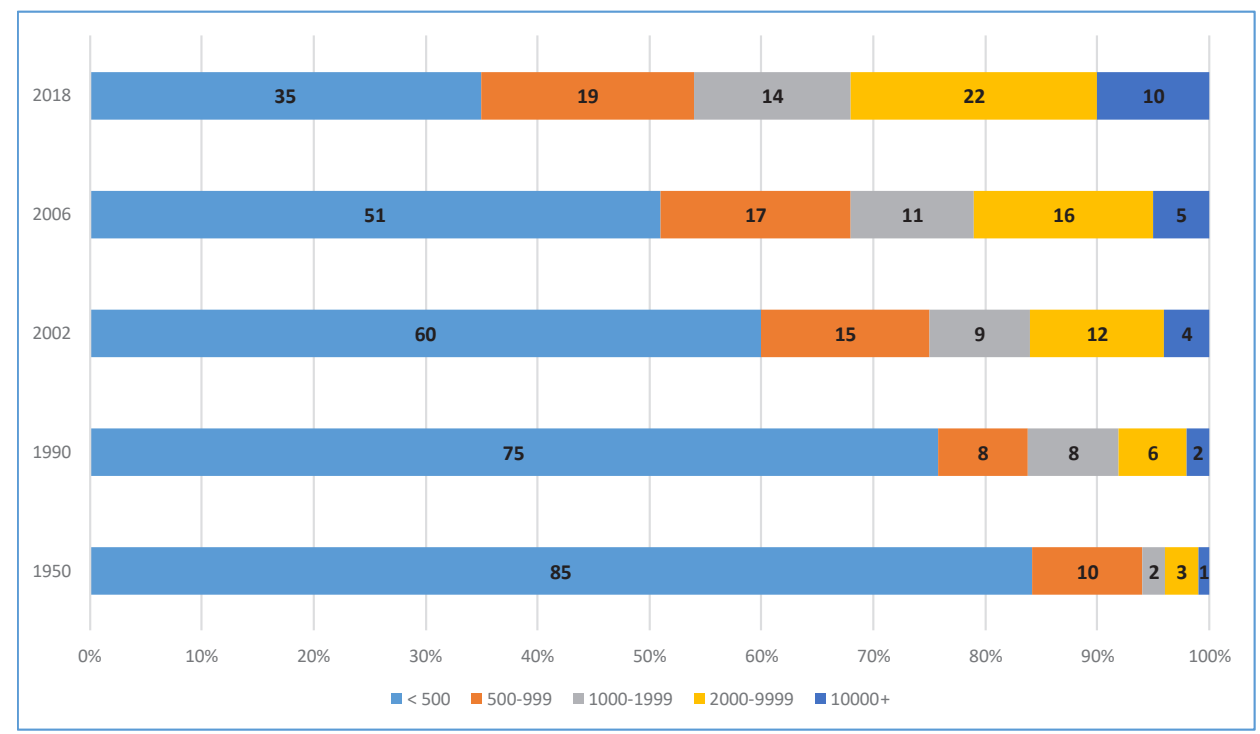

Figure 1. Municipalities in Iceland in different size categories $1950-2018^{3}$

A decade with two referenda on amalgamations certainly achieved results, but the core problem was not fully remedied. In a way, amalgamations as a solution had reached a terminal state. The Parliament, (Althing $)$, was always and has always been unwilling to force this process by legislation on the minimum size of a municipality (Eythórsson 1998). For those wanting to reinforce the municipal level by transfer of tasks from the state, something else had to be done (Eythórsson 1998; Eythórsson 2012). Eventually, interest in increased inter-municipal cooperation was awakened. The primary school had been transferred from the state to the local level in 1996 and in 2006/2007 interest in further transfers intensified. The handicap services were transferred in 2011 as part of a strategy to decentralize more welfare services from the state. Elderly care and health care centres were to follow and upper secondary schools were even discussed. A reinforcement of the municipal level, with transfers of tasks to the municipalities through inter-municipal cooperation projects, became the optimal solution and a serious alternative after the "defeat" of the amalgamation method (Eythórsson 2012, 2014a, 2014b). However, the step taken in 2011, when services for individuals with handicaps were transferred, is the only one so far. 


\subsection{Inter-municipal cooperation in Iceland}

Inter-municipal cooperation (IMC) in Iceland has a history of many decades, as there has been significant cooperation between smaller municipalities in order to cope with the provision of services which, in many cases, they could not easily provide by themselves. Inter-municipal cooperation was voluntary until the Local Government Act of 1986, but based on special agreements or contracts between institutions if they wanted to join forces on certain issues or services. With the Act in 1986, voluntary cooperation was made a free choice for those who wanted (Grétarsson 2013, 98-99).

No specific form of IMC is compulsory even though in some cases it is considered a duty or a moral duty to join certain cooperation arrangements such as regional federations of municipalities and regional economic development centres. However, municipalities are not obliged to be members of these, although there are very few exceptions from membership. When the municipal level took over the responsibility for handicap services in 2011 it turned out be compulsory, at least for the smaller municipalities. The required minimum size of a municipality for running the services was a population of 8,000 (Samkomulag ríkis og sveitarfélaga um tilferslu pjónustu vid fatlada 2010 [Agreement between state and municipalities regarding the transfer of services for people with handicaps]). Only 7 out of 74 municipalities in the country at that time attained that minimum so something had to be done and a form of cooperation had to be introduced. In five cases a single municipality runs the handicap services, whereof two have been granted a dispensation due to special geographical conditions. In two cases a larger municipality has a contract with a smaller neighbouring municipality or municipalities. In eight instances the handicap services are operated in the form of inter-municipal cooperation as a permanent arrangement. There are ten different cooperation entities. The number of municipalities involved in any form of cooperation is $67 / 72$ so only five are totally absent. Thus, in this sense most of the municipalities were in fact obliged to take part in cooperation projects. Nevertheless, the sector is strictly state-regulated and the municipalities are rigorously controlled by laws and regulations. All other inter-municipal cooperation projects are voluntary in such a way that the municipalities can decide for themselves whether they want to be members or not.

In late April 2016 a project that mapped inter-municipal cooperation in Iceland was completed (Jóhannesson et al. 2016). The main aim of the project was to map the scope and content of inter-municipal cooperation entities in the whole country, as well as implementing a survey on inter-municipal cooperation among all elected local officials. In total, 197 formal cooperation arrangements were identified throughout the country and the average involvement of a municipality in a cooperation arrangement was found to be 13.5. This, however, varied considerably by municipal population size and was significantly less in municipalities with a population of more than 2500 as table 1 shows). 
Table 1. Inter-municipal cooperation arrangements in Iceland 2016

\begin{tabular}{lcccc}
\hline Population & Mean & Median & Range & N \\
\hline 500 and less & 14.3 & 15.0 & $5-22$ & 26 \\
$501-1000$ & 14.0 & 15.0 & $8-21$ & 15 \\
$1001-2500$ & 14.3 & 14.0 & $9-22$ & 15 \\
$2501-10000$ & 11.8 & 11.0 & $6-21$ & 12 \\
$>10000$ & 10.5 & 8.5 & $7-17$ & 6 \\
\hline All & 13.5 & 14.0 & $5-22$ & 74 \\
\hline
\end{tabular}

Mean frequency of arrangements and range by population size of municipalities

Looking at cooperation by tasks as shown in figure 1 below, the most frequent areas of cooperation are Social services (36) and Primary school (30). Culture and Museums (23) and Public security and Fire brigade (22) are issues that come behind, but are significantly more frequent than other tasks. (Jóhannesson et al. 2016; Eythórsson 2018).

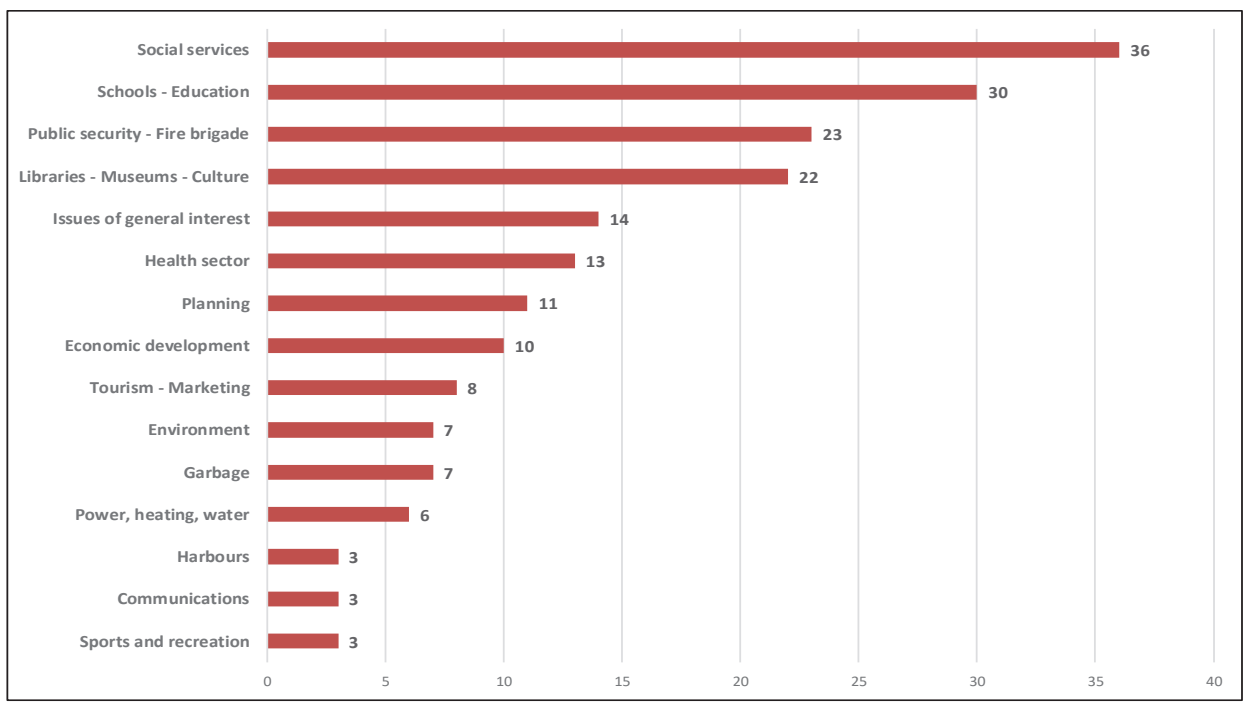

Figure 2. Inter-municipal cooperation in Iceland 2016 by tasks (N)

\section{Inter-municipal cooperation: Motives and concerns}

Academic literature on inter-municipal cooperation does not extend far back in time. However, a considerable variety of material exists on motives, experiences, advantages and disadvantages or problems with inter-municipal cooperation. This section discusses the main motives for, and the obstacles against, inter-municipal cooperation as presented in research material. 


\subsection{Motives for entering cooperation}

Research evidence has shown that a somewhat strong and widespread consideration behind entering inter-municipal cooperation arrangements is to gain economy of scale for the municipalities involved. This has also to do with gains in service quality, service capacity and administrative capacity. Several studies have pointed these out as strong drivers behind municipalities entering inter-municipal cooperation arrangements (Eythórsson 2018; Teles \& Swianiewicz 2018; Wiberg \& Limani 2015; Jacobsen 2014, Swianiewicz 2011; Baldersheim \& Rose 2010; Hulst \& van Montfort 2007; Lundtorp \& Weber 2001). "The improvement of performance for the citizens (in terms of effectiveness, efficiency and legitimacy) is a key function of local public sector reforms." (Schwab et al. 2017). In the almost 20 year old study of IMC projects in Denmark, Lundtorp and Weber (2001) found that professional capacity and service quality clearly increased in municipalities which entered the cooperation arrangements. Furthermore, one main benefit was reduction of costs; thus the municipalities achieved the same or better quality at lower or at least the same prices (Lundtorp \& Weber 2001, 77-78). The more recent Nordic study from Sweden by Wiberg and Limani (2015) showed clear signs of the collaborative profile meeting needs for higher cost efficiency and competence among staff in three Swedish municipalities. Even though Jacobsen (2014) recognizes the gain of scale-economy in inter-municipal cooperation arrangements in his Norwegian study, he points out that this can vary significantly between types of services and he concludes that the cooperation solution is not fully as good an alternative as the amalgamation of municipalities (Jacobsen 2014, 191-192).

Icelandic studies have clearly suggested the motives and effects of scale-economy, effectiveness and efficiency, such as Ragnarsson (2003) who found clear signs of scale economy and, therefore, reduced expenditure as a consequence of inter-municipal cooperation arrangements. Other studies point in the same direction (Hlynsdóttir 2004; Arnardóttir 2011; Sveinsson 2014; Eythórsson 2018). The newest and most comprehensive findings are by Eythórsson (2018) who, in two different surveys, found that the strongest reason for municipalities entering cooperation arrangements was being able to successfully deal with problems or tasks which were beyond the scope of one municipality. In addition, another frequent motive was lowering costs, thus providing opportunities for economy of scale and reduced expenses. Eythórsson's results clearly indicated that smaller municipalities tended to try to solve their scale, professionalism and capacity problems by cooperating with other municipalities, preferably joining a larger unit, and that they saw cooperation as an attractive choice, rather than risking entry into a somewhat peripheral, powerless situation with low status, in an amalgamated municipality (Eythórsson 2018).

In a broader context, however, the findings seem more mixed. In a book on intermunicipal cooperation in Central and Eastern Europe Swianiewicz brings up several main benefits of joining inter-municipal cooperation. Firstly, he refers to added economies of scale and service delivering capacity for small municipalities which join the cooperation. Secondly, cooperation prevents 'free-riding' if the catchment area of one- 
municipality is wider than administrative boundaries with neighbouring municipalities. The third benefit identified is the joint management of indivisible infrastructure. The fourth advantage is that it might be better, or even necessary, to manage functionally integrated services in administratively fragmented areas. The fifth source of strength is enhanced visibility for smaller entities which lack capacity for the effective promotion of, for example, tourism. The sixth and last item mentioned by Swianiewicz is improved potential access to funding - not least EU funding (Swianiewicz 2011). Raudla and Tavares (2018) suggest that one of the factors facilitating the development of IMC in contemporary Europe has been the economic crisis and the austerity measures taken by central governments. First, as a reaction to the situation by seeking economies of scale and second, because a crisis makes institutions and leaders seek reforms as a way to tackle the crisis situation (Raudla \& Tavares 2018, 341-342).

There seems to be mixed evidence on the reasons for entering inter-municipal cooperation, not least for smaller municipalities which often seek the option of a scaleeconomy. But do these reasons for joining forces with IMC offer results without any disadvantages? Since the evidence from Iceland appears rather one-sided, unlike that from all other European countries, does this mean that the disadvantages there are different or even lacking?

\subsection{The more sceptical views: Democracy, accountability and efficiency}

Democratic concerns connected to inter-municipal cooperation arrangements have been raised by various scholars, especially in Europe. These mostly relate to the complexity of accountability and decision-making. Voters in local government elections delegate their power to their directly elected politicians, in itself a delegation of authority, which in principle, could be a problem. This is a fundamental aspect of representative democracy. What is not necessarily included in representative democracy, however, is the situation when elected officials in municipal councils further delegate their authority to another board or council, in no way elected by their voters. Thus, a democratic dilemma can occur.

In a report on inter-municipal cooperation in Denmark, the Danish political scientist Ulrik Kjær mentioned several 'potential concerns on democracy' connected to intermunicipal cooperation projects (Kjær 2000). The first was that the political minority on each municipal board involved in cooperation is, or can be, undermined since it is more commonly a representative from the political majority of a council who represents the municipality on the IMC board. The second concern is that having only one representative on these IMC boards leads to fewer possibilities of monitoring that the interests of each municipality are taken care of. A third consideration is that political accountability can be diffuse. The voters have problems realizing which politician in their municipality is responsible for the decisions of an IMC board (Kjær 2000, 11). However, in another research project on inter-municipal cooperation in Denmark these concerns about democracy received much less support. The Danes Lundtorp and Weber (2001) argued that their research findings did not confirm the democratic concerns expressed by Kjær (Lundtorp \& Weber 2001, 73-74). 
Nor does earlier Icelandic research on this topic seem to support these kinds of concerns regarding the democratic deficit. In Finland, criticism has mostly focused on overgrown, inefficient and, therefore, expensive administration in the context of intermunicipal cooperation - not on the democratic aspect (Pekola-Sjöblom 1998).

More recent European research results identify democratic deficits, slow decisionmaking, and increased personnel and political costs as unfavourable consequences of cooperation. First, Swianiewicz (2011) maintains that democratic deficits are caused by several factors such as unclear decision making procedures which are not as transparent as in local government, less transparency in decision-making, ambiguous answers to the question as to who is in charge, how budget control is regulated, and how local councils and citizens are informed about decisions. He even raises the possibility that IMC arrangements can be vulnerable to corruption. Second, he identifies slow decision-making as a consequence of complicated procedures and lack of hierarchal provisions to get out of deadlocks. Third, he brings up the political costs for (at least) some politicians of delegating their power and sharing their prestige and pride with politicians from other municipalities, which can weaken the ability to cooperate. (Swianiewicz 2011, 8).

Gutlic (2011) sees accountability problems as obstacles to inter-municipal cooperation due to the uncertainty as to who is responsible. In her empirical study in Sweden this is confirmed - some of her respondents talk about this as making cooperation difficult and that one "driving" person with a clear mandate would definitely help in IMC arrangements.

Denters (2017) has very recently written about participation and democratic accountability in inter-municipal cooperation arrangements. He points out that the democratic control and accountability of IMC is normally concentrated in the hands of directly elected councils, which can cause this IMC arrangement not to function. Democratically, the channels for citizen control will be indirect since the members of IMC councils or boards are elected by local councilors who are directly elected. Furthermore, the position of elected municipal councilors is weak since they are not well equipped to exercise control over IMCs. Finally, accountability is uncertain in such multi-actor settings as IMCs are. On efficiency and decision-making, Denters notes that there are no distinct incentives for effectiveness and efficiency because it is unclear who benefits from the success of the IMC arrangements or takes the blame for their failures. Moreover, IMCs can be costly systems due to high transaction costs and ineffective due to long drawnout decision-making. He concludes that calls for new forms of democratic control and accountability come as no surprise and become even louder when the task scope broadens (Denters 2017).

\section{Local leaders' attitudes to inter-municipal cooperation}

The data analysis aiming to answer the research questions in this paper originates from two data sets. One is from a net-survey questionnaire, mailed in spring 2015 to all elected local politicians in the Faroe Islands, Greenland and Iceland as part of the research project "West Nordic Municipal Structure", financed by The Arctic Cooperation Fund. In 
this case only the answers from the Icelandic leaders are analysed. The questions were on several topics; mainly on structural reforms, local democracy and local and regional entrepreneurship. The final response rate was 54 percent (263/487) (Eythórsson et al. 2015).

The other survey was sent out in spring 2016 to all elected local officials in the country; this time as part of the research project "Samstarfsverkefni Sveitarfélaga" [InterMunicipal Cooperation in Iceland] (see Jóhannesson et al. 2016). In the survey, local elected officials were asked various questions on inter-municipal cooperation. The final response rate was 53 percent (258/489) (Jóhannesson et al. 2016).

In both cases the respondents were asked whether they agreed or disagreed with different statements. The statements were about inter-municipal cooperation in general but their answers are understood as expressing their judgement, based on experience in their own municipality and its IMC context and background.

\subsection{Accountability}

In both surveys, the respondents were asked about accountability in the context of IMCs. In one of them, the statement in question focused on the complexity of accountability and the direct wording of the other related to problems due to unclear accountability ("Inter-municipal cooperation can be problematic due to unclear accountability"). These predicaments and the concerns behind them are raised for example by Kjær (2000), Gutlic (2011) and by Denters (2017) as seen above.

In both surveys reported here, strong support for the statements on uncertain accountability is evident. In the 2016 survey a solid majority believes that accountability is not clear in inter-municipal cooperation arrangements (table 2). This attitude is fairly even among leaders in municipalities with different population sizes. Between 75 and 87 percent agree or strongly agree with the statement.

Table 2. "Inter-municipal cooperation can be problematic due to unclear accountability"

\begin{tabular}{lcccccc}
\hline $\begin{array}{l}\text { Population in } \\
\text { municipality }\end{array}$ & $\begin{array}{c}\text { Strongly } \\
\text { agree }\end{array}$ & Agree & Disagree & $\begin{array}{c}\text { Strongly } \\
\text { disagree }\end{array}$ & N & \multicolumn{2}{c}{ Balance score } \\
\hline 500 and less & $26 \%$ & $49 \%$ & $26 \%$ & $0 \%$ & 39 & $49 \%$ \\
$501-1000$ & $24 \%$ & $53 \%$ & $18 \%$ & $4 \%$ & 45 & $56 \%$ \\
$1001-2500$ & $31 \%$ & $56 \%$ & $13 \%$ & $0 \%$ & 45 & $73 \%$ \\
$2501-10.000$ & $30 \%$ & $49 \%$ & $19 \%$ & $2 \%$ & 47 & $57 \%$ \\
More than 10.000 & $32 \%$ & $53 \%$ & $11 \%$ & $5 \%$ & 19 & $68 \%$ \\
\hline Total & $28 \%$ & $52 \%$ & $18 \%$ & $2 \%$ & 195 & $60 \%$ \\
\hline
\end{tabular}

Balance score $=$ Strongly agree plus Agree - Strongly disagree plus Disagree. 
The same tendency is shown in the survey from 2015 although on a different measurement scale. On the scale $1-7$ the mean scores are all above the mid-point of $4-$ the lowest at 4.56 and the highest is 5.56 . These scores are $65-79$ percent of the scale on the "agree side" so we see a very similar pattern in both surveys.

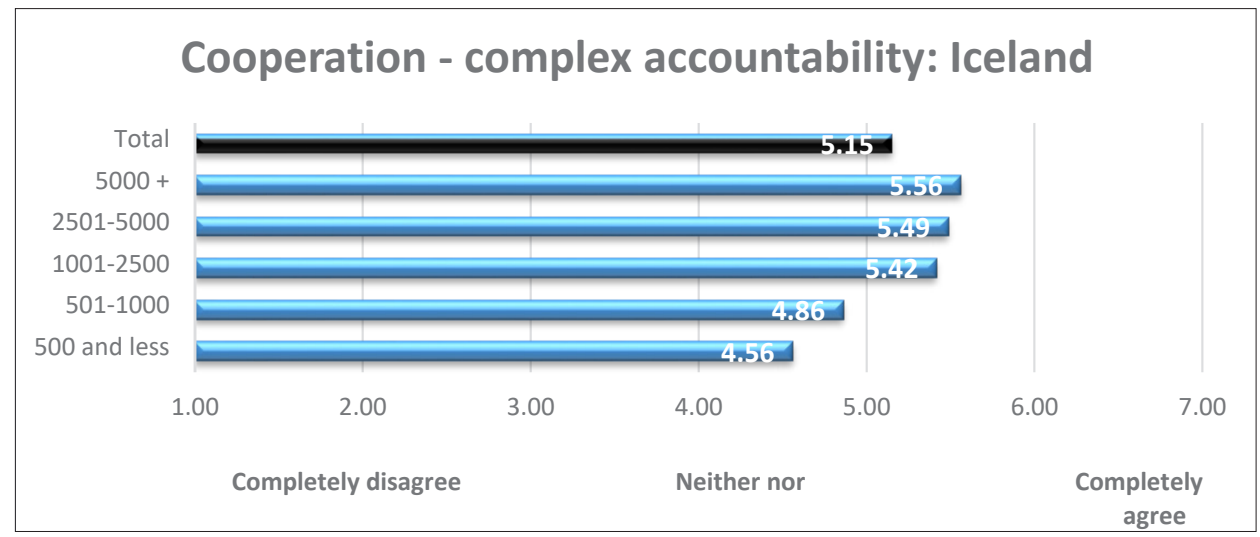

Figure 3. "Inter-municipal cooperation can be problematic due to complex accountability". Iceland

Mean scores on a scale 1-7 on the above statement (1=Completely disagree; $7=$ Completely agree $).(N=243)$

Further, we see from Figure 3 that accountability is believed to be complex or unclear in IMCs in all size categories of municipalities. However, a pattern seems to emerge to the effect that this belief is stronger in municipalities with a population of more than 1000 .

Accountability seems to be a definite concern in the context of inter-municipal cooperation in Iceland - at least among elected local councilors.

\subsection{Efficiency and decision-making}

Complexity and/or inefficiency in decision-making in inter-municipal cooperation is argued in almost all the research findings quoted above (Pekola-Sjöblom 1998; Gutlic 2011; Swianiewicz 2011; Denters 2017). However, no research in Iceland has ever suggested a parallel trend, except Hlynsdóttir's qualitative research on IMCs in South Iceland from 2004.

In brief, the two surveys from 2015 and 2016 show that this belief is widespread among local leaders; that is, inefficiency in decision making is apparent in IMCs. From 75 to 90 percent of the leaders in the 2016 survey "Strongly agree" or "Agree" with the statement that IMCs are problematic due to inefficiency in decision-making. This represents a huge majority in all size categories so the point seems hardly questionable. 
Table 3. "Inter-municipal cooperation can be problematic due to inefficient decision-making"

\begin{tabular}{lcccccc}
\hline $\begin{array}{l}\text { Population in } \\
\text { municipality }\end{array}$ & $\begin{array}{c}\text { Strongly } \\
\text { agree }\end{array}$ & Agree & Disagree & $\begin{array}{c}\text { Strongly } \\
\text { disagree }\end{array}$ & N & \multicolumn{2}{c}{ Balance score } \\
\hline 500 and less & $26 \%$ & $49 \%$ & $23 \%$ & $3 \%$ & 39 & $49 \%$ \\
$501-1000$ & $27 \%$ & $48 \%$ & $23 \%$ & $2 \%$ & 44 & $50 \%$ \\
$1001-2500$ & $30 \%$ & $57 \%$ & $14 \%$ & $0 \%$ & 44 & $73 \%$ \\
$2501-10.000$ & $30 \%$ & $53 \%$ & $13 \%$ & $4 \%$ & 47 & $66 \%$ \\
More than 10.000 & $32 \%$ & $58 \%$ & $5 \%$ & $5 \%$ & 19 & $79 \%$ \\
\hline Total & $28 \%$ & $53 \%$ & $16 \%$ & $3 \%$ & 194 & $62 \%$ \\
\hline
\end{tabular}

Balance score $=$ Strongly agree plus Agree - Strongly disagree plus Disagree.

The survey from 2015 clearly shows the same pattern. A sound majority in all municipal size categories agrees with the statement that IMC can be problematic due to complexity in decision-making. But, as in the case of accountability above, the views differ slightly, however, between larger and smaller municipalities. There is apparently a greater emphasis on the problem among leaders in the larger municipalities - that is, with a population of more than 1000 .

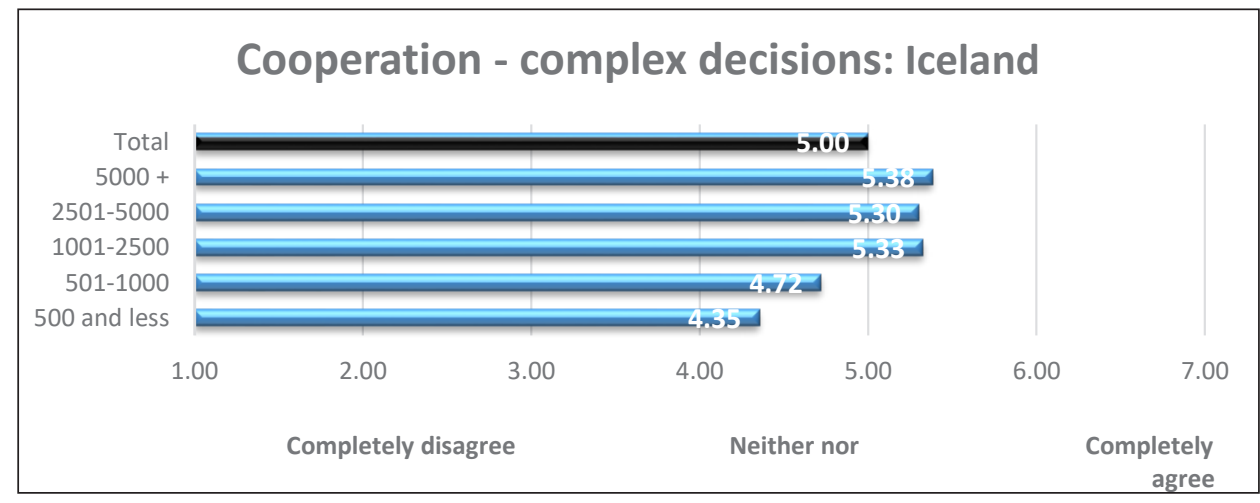

Figure 4. "Inter-municipal cooperation can be problematic due to complex decision making". Iceland

Mean scores on a scale 1-7 on the above statement ( $1=$ Completely disagree; $7=$ Completely agree $)$. $(\mathrm{N}=242)$

To sum up, the Icelandic elected local leaders seem to believe strongly that inter-municipal cooperation can cause complex and inefficient decision-making.

\subsection{Overview}

When some of the municipal services are provided directly by the individual municipalities and some through cooperation arrangements with others, things can get more complicated for both the citizens and the politicians. Even what services are offered can 
be less transparent. In quite a number of cases the IMC arrangements have their own webpages where the services are presented. This does not necessarily mean that the same IMCs are presented or accessible on the web pages of the individual municipalities. A survey among directors of 50 inter-municipal cooperation arrangements in Iceland conducted in February/March 2015 showed that in 60 percent of cases the citizens are informed about the activities of IMCs on IMC webpages and only 43 percent on the webpages of the municipalities concerned (Eythórsson 2017; Eythórsson 2015). This means that in less than half the cases, citizens can access information through their own municipality's webpage. Should they manage or bother to look up the webpage of the IMC, no more than 6 out of 10 have one. This does not help citizens or politicians to obtain proper information or overview of the services.

In the survey from 2016 the local leaders were asked about this - one question on their own overview and another on their evaluation of the overview of the citizens. In table 4 we see rather clear results. Local leaders do not believe that IMCs improve citizens' overview of services available to them. In actual fact the opposite is the case - the citizens have less overview, I dare say. From 62 to 78 percent of them disagree or strongly disagree with the statement in different size categories. It is only in the smallest municipalities where a majority of them agrees (64\%).

Table 4. Inter-municipal cooperation improves citizens' overview of services they can be provided with

\begin{tabular}{lcccccc|c|c}
\hline $\begin{array}{l}\text { Population in } \\
\text { municipality }\end{array}$ & $\begin{array}{c}\text { Strongly } \\
\text { agree }\end{array}$ & Agree & Disagree & $\begin{array}{c}\text { Strongly } \\
\text { disagree }\end{array}$ & N & \multicolumn{3}{c}{ Balance score } \\
\hline 500 and less & $11 \%$ & $53 \%$ & $28 \%$ & $8 \%$ & 36 & & $28 \%$ \\
$501-1000$ & $2 \%$ & $32 \%$ & $56 \%$ & $10 \%$ & 41 & $-32 \%$ & & \\
$1001-2500$ & $0 \%$ & $38 \%$ & $51 \%$ & $11 \%$ & 37 & $-24 \%$ & & \\
$2501-10.000$ & $5 \%$ & $18 \%$ & $64 \%$ & $14 \%$ & 44 & $-55 \%$ & \\
More than 10.000 & $6 \%$ & $29 \%$ & $53 \%$ & $12 \%$ & 17 & $-29 \%$ & \\
\hline Total & $5 \%$ & $34 \%$ & $51 \%$ & $11 \%$ & 175 & $-23 \%$ & & \\
\hline
\end{tabular}

Balance score $=$ Strongly agree plus Agree - Strongly disagree plus Disagree.

In the following table (table 5) we see the responses of the local leaders themselves on the same question. Their views appear to be more split. In the larger municipalities (2500 and more) over 60 percent of the leaders disagree, which means that they feel there is less overview. In the smallest municipalities (1000 and less) this is the opposite (36-41\%). 
Table 5. "Inter-municipal cooperation improves politicians' overview of services provided by the municipality"

\begin{tabular}{|c|c|c|c|c|c|c|c|}
\hline $\begin{array}{l}\text { Population in } \\
\text { municipality }\end{array}$ & $\begin{array}{l}\text { Strongly } \\
\text { agree }\end{array}$ & Agree & Disagree & $\begin{array}{l}\text { Strongly } \\
\text { disagree }\end{array}$ & $\mathrm{N}$ & \multicolumn{2}{|c|}{ Balance score } \\
\hline 500 and less & $17 \%$ & $42 \%$ & $33 \%$ & $8 \%$ & 36 & & $17 \%$ \\
\hline $501-1000$ & $9 \%$ & $56 \%$ & $27 \%$ & $9 \%$ & 45 & & $29 \%$ \\
\hline $1001-2500$ & $3 \%$ & $48 \%$ & $40 \%$ & $10 \%$ & 40 & & $0 \%$ \\
\hline $2501-10.000$ & $4 \%$ & $35 \%$ & $46 \%$ & $15 \%$ & 46 & $-22 \%$ & \\
\hline More than 10.000 & $5 \%$ & $32 \%$ & $37 \%$ & $26 \%$ & 19 & $-26 \%$ & \\
\hline Total & $7 \%$ & $44 \%$ & $36 \%$ & $12 \%$ & 187 & & $3 \%$ \\
\hline
\end{tabular}

Balance score $=$ Strongly agree plus Agree - Strongly disagree plus Disagree.

A similar pattern shows up in the responses to both questions, although more divided on the overview of the leaders themselves. In the larger municipalities, the overview is not believed to improve with IMCs, although this is the case in the smaller ones. The opinion seems to be more divided among the leaders than what they think applies to the citizens. An explanation of these differences in relation to population size is not obvious and probably needs further investigation, for example, by means of interviews or focus group methods.

\subsection{Democracy}

The last analysis conducted in this paper is on a general evaluation by local leaders in Iceland as to whether inter-municipal cooperation is a democratic way of providing municipal services. Above, we have analyzed and discussed several democratic aspects of IMCs but, as the next statement is phrased, it should be considered as a quest for a general evaluation of whether inter-municipal cooperation as such is democratic. We have seen that there are widespread doubts on accountability and efficiency in decisionmaking when it comes to IMC. Therefore, the results in table 6 are surprising: A strong majority of local leaders believe that IMCs are a democratic way of providing services to citizens, except in the six largest municipalities where the opinion is 50/50. In the other categories, those who agree or strongly agree are $62-82$ percent. 
Table 6. "Inter-municipal cooperation is a democratic way of providing services to citizens"

\begin{tabular}{lcccccc}
\hline $\begin{array}{l}\text { Population in } \\
\text { municipality }\end{array}$ & $\begin{array}{c}\text { Strongly } \\
\text { agree }\end{array}$ & Agree & Disagree & $\begin{array}{c}\text { Strongly } \\
\text { disagree }\end{array}$ & N & Balance score \\
\hline 500 and less & $26 \%$ & $56 \%$ & $15 \%$ & $3 \%$ & 39 & $64 \%$ \\
$501-1000$ & $5 \%$ & $57 \%$ & $26 \%$ & $12 \%$ & 42 & $24 \%$ \\
$1001-2500$ & $14 \%$ & $55 \%$ & $25 \%$ & $7 \%$ & 44 & $36 \%$ \\
$2501-10.000$ & $7 \%$ & $55 \%$ & $25 \%$ & $14 \%$ & 44 & $23 \%$ \\
More than 10.000 & $6 \%$ & $44 \%$ & $19 \%$ & $31 \%$ & 16 & $0 \%$ \\
\hline Total & $12 \%$ & $55 \%$ & $23 \%$ & $11 \%$ & 186 & $33 \%$ \\
\hline
\end{tabular}

Balance score $=$ Strongly agree plus Agree - Strongly disagree plus Disagree.

\section{Concluding discussion}

The results presented in this article are based on two different surveys among the same population of elected local politicians in Iceland. Both show clear patterns in local leaders' attitudes and opinions on inter-municipal cooperation arrangements with regard to some democratic aspects. Despite a slightly different wording between surveys, the topics and concepts should be clear enough. The Icelandic local government sector is not extensive and discussions on municipal affairs usually reach a good share of the leaders, both in their annual meetings or their sectoral journals. This increases the probability of their mutual understanding of topics raised in the surveys.

Summing up the results from the analysis, we begin by saying that democratic accountability is definitely a concern and that among the elected local councilors in Iceland it is considered somewhat problematic in the context of inter-municipal cooperation. The main pattern is that this tends to be the belief of leaders in municipalities with a population of more than a 1000 rather than of those in the smallest ones. Inefficiency in decisionmaking in inter-municipal cooperation arrangements is widely argued in research findings on inter-municipal cooperation and democracy. In the case of Iceland, as shown in data from local leader surveys, it is found to be a strong conviction that inter-municipal cooperation can cause complex and inefficient decision-making situations, thus being less efficient than local government processes where services are provided by a single municipality.

As regards the questions whether IMC arrangements give more comprehensive and better overview of service provision the main answer is negative. This is, however, to some extent related to municipal size - a majority of the leaders in the smallest municipalities believe that efficiency and overview is gained by joining IMCs.

This evidence certainly lends support to the more sceptical views put forward by various scholars (Pekola-Sjöblom 1998, Kjær 2000, Gutlic 2011, Swianiewicz 2011 and Denters 2017). Inter-municipal cooperation in Iceland has its advantages through increased capacity and economy of size, but it also seems to experience these democracy-related concerns. The general misgivings stated by the above-mentioned European 
researchers, therefore, seem to be present in the case of inter-municipal cooperation in Iceland. However, looking further at the results from the Icelandic case it is rather surprising to see that in the last table presented in the paper we find a strong majority of local leaders agreeing with the statement that inter-municipal cooperation is a democratic way of providing services!

This raises some questions. Do Icelandic local leaders really think that inter-municipal cooperation is a democratic way of providing services, but still see various downsides of this form? Or do they understand or define the concept "democracy" in another way than including democratic accountability and decision-making efficiency? Or are the problems with accountability and decision-making efficiency not conspicuous enough to affect the general judgement as to whether IMC is a democratic way to provide services or not? We have to bear in mind that the data we are analysing in this article is from surveys among the "elite" - elected local politicians. Do they evaluate these issues differently from ordinary citizens? Would we perhaps get divergent results in a citizen survey? This final question cannot be answered here, but it would be interesting to see how citizens responded. Nevertheless, local leaders in Iceland do agree that there are concerns relating to the institutional arrangement of inter-municipal cooperation.

\section{Notes}

1 Source: www.hagstofa.is

2 Association of Local Authorities in Iceland September 2018.

3 Source: Iceland Statistics (Hagstofa Íslands) www.hagstofa.is

\section{References}

Arnardóttir, J.E (2011). Samtök sveitarfélaga á Vesturlandi. Samstarf eða vísir að pridja stjórnsyislustigi? [Federation of Municipalities in West Iceland. Cooperation or indication of a new governmental tier?] (MPA-thesis). University of Iceland, Reykjavík.

Association of Local Authorities in Iceland (2018). Local Governments in Iceland. Facts and Figures. Retrieved from https://www.samband.is/media/tolfraedilegar-upplysingar/Enskur_Baeklingur_sept_2018. pdf

Baldersheim, H., and Rose L. (2010). "Territorial Choice: Rescaling Governance in European States", in H. Baldersheim and L. Rose (eds.), Territorial Choice. The Politics of Boundaries and Borders (pp.1-21). London: Palgrave Macmillan.

Denters, B. (2017). "Participation, and Democratic Accountability: Making a difference for the Citizens", in C. Schwab, G. Bouckaert, and S. Kuhlmann (eds.), The Future of Local Government in Europe. Lessons from Research and Practice in 31 countries (pp. 79-100). Baden Baden: NOMOS.

Etzioni, A. (1970). Moderna Organisationer [Modern Organisations]. Lund: Berlingska Boktryckeriet.

Eythórsson, G.T (2018). "Bigger and stronger together. How Icelandic municipalities solve their lack of capacity and scale economy”, in F. Teles and P. Swianiewicz (eds.), Inter-municipal cooperation in Europe. Institutions and Governance. Palgrave MacMillan.

Eythórsson, G.T. (2015). Inter-Municipal Cooperation in Iceland. Results from the survey. Presented at 4th General COST-LocRef MC and WG Meeting. Local Public Sector Reforms: An International Comparison (LocRef IS 1207) held in Dubrovnik (Croatia), 05/06 May 2015.

Eythórsson, G.T. (2012). "Efling íslenska sveitarstjórnarstigsins. Áherslur, hugmyndir og aðgerðir” [Reinforcing the municipal level in Iceland. Ideas, policies and implementations], The Icelandic Review of Politics \& Administration 2(8), 431-450. Retrieved from http://www.irpa.is/article/view/1187 
Eythórsson, G.T. (2009). "Municipal amalgamations in Iceland. Past, present and future", in G. Baldacchino, R. Greenwood, and L. Felt (eds.), Remote Control. Governance Lessons for and from Small, Insular, and Remote Regions. St. John's: Iser Books.

Eythórsson, G.T. (1998). Kommunindelningspolitik i Island. Staten, kommunerna och folket om kommunsammanslagningar [Municipal structure in Iceland. The state, the municipalities and the people on municipal amalgamations]. Göteborg: CEFOS.

Eythórsson, G.T., Gløersen, E., and Karlsson, V. (2015). Municipalities in the Arctic in Challenging times. West Nordic local politicians and administrators on municipal structure, local democracy, service provision and adaptive capacity in their municipalities. Akureyri: University of Akureyri. Retrieved from http://ssv.is/Files/ Skra_0072561.pdf

Eythórsson G.T., Gløersen, E., and Karlsson, V. (2014). West Nordic municipal structure: Challenges for local democracy, efficient service provision and adaptive capacity. Report from a project supported by the Arctic Co-operation Programme 2012-2014. Akureyri: RHA. Retrieved from http://ssv.is/Files/ Skra_0071836.pdf

Eythórsson G.T., Sveinsdóttir, H., and Jóhannesdóttir, K. (2006). Íslenska sveitarstjórnarstigið - viðhorf stjórnmálamanna. Könnun meðal sveitarstjórnarmanna og Alpingismanna [The Icelandic Municipal System. Survey among local administrators and members of parliament]. Borgarbyggð: Rannsóknamiðstöð Háskólans á Bifröst.

Grétarsson, I.E. (2013). Sveitarfélög á Íslandi 1872 - 2012. Lýdraði i löggö̈f. Forsaga laga og ferli endurskodunar [Municipalities in Iceland 1872 - 2012. Democracy in legislation] (MPA-thesis). University of Iceland, Reykjavík.

Gutlic, S. (2011). Samverkan mellan kommuner - en fallstudie om fyra kommuner i Västra Götaland Intermunicipal cooperation - a case study of four municipalities in West Gothland] (Master's-thesis in public administration). Göteborg University, Sweden.

Hlynsdóttir, E.M (2001). Sveitarfélagið Skagafjördur. Staða lýðraðis i sameinudu sveitarfélagi [Skagafjörður Municipality. The democratic situation in an amalgamated municipality] (BA-thesis). University of Iceland, Reykjavík.

Hlynsdóttir, E.M. (2004). Uppsveitir Árnessýslu: Samstarf eða sameining? [Upper Árnessýsla: Inter-municipal cooperation or amalgamation?] (MA-thesis). University of Iceland, Reykjavík.

Hulst, R., and Van Montfort, A. (eds.) (2007). Inter-municipal cooperation in Europe (Vol. 238). Dordrecht: Springer.

Iceland Statistics (n.d.). Retrieved from www.hagstofa.is

Icelandic Ministry of Welfare. Retrieved from https://www.velferdarraduneyti.is/yfirfaersla/umverkefnid/

Jóhannesson, A., Jóhannesson, H., and Eythórsson, G.T. (2016). Samstarfsverkefni Sveitarfélaga. [Intermunicipal cooperation in Iceland]. Akureyri: University of Akureyri Research Centre.

Karlsson, V., and Jóhannesson, T. (2014). Sameiningar sveitarfélaga á Vesturlandi. Möguleikear nokekurra valkosta og hugsanleg ábrif peirra árid 2014. [Municipal amalgamations in West Iceland. Opportunities associated with certain options and their potential impact in 2014] Borgarnes: SSV. Retrieved from http://www.ssv.is/Files/Skra_0069071.pdf

Kjær, U. (2000). Kommunale samarbejder og demokratisk, control [Municipal cooperation and democratic administration]. Copenhagen: KL - Local Government Denmark.

Lundtorp, S. and, Weber, M. (2001). Kommunalt Samarbejde. Nu og i fremtiden [Municipal cooperation. Now and in the future]. Copenhagen: KL - Local Government Denmark.

Pekola-Sjöblom, M. (1998). JOINT MUNICIPAL AUTHORITIES - AN EFFECTIVE AND DEMOCRATIC FORM OF COOPERATION BETWEEN MUNICIPALITIES? Unpublished paper.

Ragnarsson, R. (2003). Samvinna sveitarfélaga á Íslandi. Valkostur við sameiningu? [Inter-municipal cooperation in Iceland. An alternative to amalgamations?] (MA-thesis). University of Iceland, Reykjavík.

Raudla, R., and Tavares, A. (2017). "Inter-municipal Cooperation and Austerity Policies: Obstacles or 
Opportunities?”, in C. Schwab, G. Bouckaert, and S. Kuhlmann (eds.), The Future of Local Government in Europe. Lessons from Research and Practice in 31 countries (pp. 53-78). Baden Baden: NOMOS.

Schwab, C., Bouckaert, G., and Kuhlman, S. (2017). "Conclusion: Lessons and Advice for Future Local Government in Europe", in C. Schwab, G. Bouckaert, and S. Kuhlmann (eds.), The Future of Local Government in Europe. Lessons from Research and Practice in 31 Countries (pp. 101-111). Baden-Baden: Nomos.

Steiner, R., Kaiser, C., and Eythórsson, G.T. (2016). "A Comparative Analysis of Amalgamation Reforms in Selected European Countries", in S. Kuhlmann and G. Bouckaert (eds.), Local Public Sector Reforms in Times of Crisis. National trajectories and international comparisons. London: Palgrave MacMillan.

Sveinsson, D. (2014). Samstarf sveitarfélaga á Vestfördum og á Nordurlandi-vestra. Ábrif samstarfs á lýdrađi og hagkevamni i rekstri sveitarfélaga [Inter-municipal cooperation in the Westfjords and North-west districts. Effect on democracy and efficiency] (MPA-thesis). University of Iceland, Reykjavík.

Swianiewicz, P. (2011). "Demanded but Difficult: Intermunicipal Cooperation in Central and Eastern Europe", in P. Swianiewicz (ed.), Working Together. Intermunicipal Cooperation in Five Central European Countries (pp. 1-18). Budapest: Open Society Foundations.

Teles, F., and Swianiewicz, P. (eds.) (2018). Inter-municipal cooperation in Europe: institutions and governance. Palgrave Macmillan.

Teles, F., and Swianiewicz, P. (2018). "Motives for Revisiting Inter-municipal Cooperation", in F. Teles and P. Swianiewicz (eds.), Inter-municipal cooperation in Europe: institutions and governance (pp. 1-13). Palgrave Macmillan.

Wiberg, U., and Limani, I. (2015). "Intermunicipal collaboration - a smart alternative for small municipalities?", Scandinavian Journal of Public Administration 19(1), 63-82. 